\title{
THE USE OF DEXMEDETOMIDINE IN PUNCTURE TECHNIQUES FOR DEGENERATIVE DISEASES OF THE LUMBAR SPINE
}

\author{
USO DE DEXMEDETOMIDINA EM TÉCNICAS DE PUNÇÃO PARA DOENÇAS DEGENERATIVAS \\ DA COLUNA LOMBAR
}

\section{USO DE DEXMEDETOMIDINA EN TÉCNICAS DE PUNCIÓN PARA ENFERMEDADES DEGENERATIVAS DE LA COLUMNA LUMBAR}

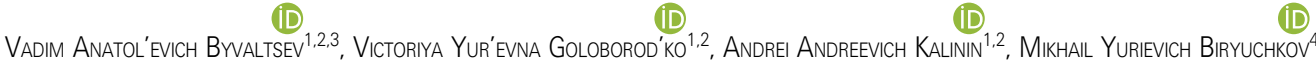 \\ 1. Railway Clinical Hospital, Irkutsk, Russia \\ 2. Irkutsk State Medical University, Irkutsk, Russia. \\ 3. Irkutsk state medical academy of postgraduate education, Irkutsk, Russia. \\ 4. West Kazakhstan Marat Ospanov Medical University, Aktobe, Kazakhstan
}

\begin{abstract}
Objective: To analyze the results of the use of dexmedetomidine (D) in the treatment of patients with degenerative diseases of the lumbar spine using puncture techniques. Methods: The study included 77 patients who underwent surgical puncture for degenerative diseases of the lumbar spine with the use of alpha-2-adrenomimetic D: percutaneous laser denervation of the facet joints ( $\mathrm{n}=46)$ and posterolateral transforaminal endoscopic discectomy $(n=31)$. We assessed: the level of sedation using the Ramsay Sedation Scale (RSS) and the Richmond Agitation Sedation Scale (RASS); intraoperative dynamics of the cardiovascular and respiratory system parameters; the level of pain syndrome according to VAS. Results: A high intraoperative level of sedation was determined, with RASS -2, -3 and Ramsay III, IV; when transferring a patient to a department (in 90 minutes) this parameter was RASS 0 and Ramsay II. There were no significant changes in central hemodynamics and respiratory depression. The minimum level of pain was determined immediately after surgery, at 30 and 60 minutes after surgery, and before transfer to the department $(90$ minutes): $6(4 ; 9) ; 10(8 ; 12) ; 12$ (9;13); 16 (13;19) respectively. The absence of the need for additional analgesia on the first postoperative day was verified. Conclusion: The use of $D$ significantly reduces the level of pain, while maintaining the necessary verbal contact with the patient, and provides the necessary neurovegetative protection without respiratory depression or lowered hemodynamic parameters during the perioperative period. Level of evidence II; Prognostic Studies - Investigating the Effect of a Patient Characteristic on Disease Outcome. Case series, retrospective study.
\end{abstract}

Keywords: Lumbar Spine; Laser Denervation of the Facet Joint; Posterolateral Transforaminal Endoscopic Discectomy; Alpha-2-adrenomimetics; Dexmedetomidine; Fast-Track Surgery; Hemodynamic Stabilization.

\section{RESUMO}

Objetivo: Analisar os resultados do uso de dexmedetomidina (D) no tratamento de pacientes com doenças degenerativas da coluna lombar com técnicas de punção. Métodos: O estudo incluiu 77 pacientes submetidos à punção cirúrgica em doenças degenerativas da coluna lombar com o uso de um agonista alfa-2 adrenérgico: denenação percutânea das articulações facetárias com laser ( $n=46)$ e discectomia endoscópica transforaminal posterolateral $(n=31)$. Foram avaliados o nível de sedação usando a Escala de Sedação de Ramsay (RSS) e a Escala de Sedação e Agitação de Richmond (RASS); a dinâmica intraoperatória dos parâmetros dos sistemas cardiovascular e respiratório; o nível de síndrome de dor de acordo com a EVA. Resultados: Determinou-se um alto nível intraoperatório de sedação pela RASS (-2, -3) e pela Ramsay (III, IV). Ao transferir um paciente para outro setor (depois de 90 minutos), esse parâmetro era 0 em RASS e II em Ramsay. Não houve alterações significativas na hemodinâmica central e na depressão respiratória. O nível mínimo de dor foi determinado imediatamente após a cirurgia, 30 e 60 minutos depois da cirurgia e antes da transferência para o outro setor (90 minutos depois): 6 (4; 9); 10 (8; 12); 12 (9; 13$) ; 16$ (13; 19$)$, respectivamente. Constatou-se que não era necessária analgesia adicional no primeiro dia pós-operatório. Conclusões: O uso de $D$ reduz significativamente o nível de dor mantendo a comunicação verbal necessária com o paciente e fornece a proteção neurovegetativa necessária sem depressão respiratória e os parâmetros hemodinâmicos reduzidos durante o período perioperatório. Nível de evidência II; Estudos prognósticos - Investigação do efeito de característica de um paciente sobre o desfecho da doença. Série de casos, Estudo retrospectivo.

Descritores: Coluna Vertebral Lombar; Articulação Facetária de Desnazamento a Laser; Discectomia Endoscópica Transforaminal Posterolateral; Alfa-2-adrenomiméticos; Dexmedetomidina; Cirurgia Acelerada; Estabilização Hemodinâmica.

\section{RESUMEN}

Objetivo: Analizar los resultados del uso de dexmedetomidina (D) en el tratamiento de pacientes con enfermedades degenerativas de la columna lumbar con técnicas de punción. Métodos: El estudio incluyó a 77 pacientes con enfermedades degenerativas de la columna lumbar que se sometieron a punción quirúrgica mediante el uso de un agonista adrenérgico alfa-2: denervación percutánea de las articulaciones 
facetarias con láser $(n=46)$ y discectomía endoscópica transforaminal posterolateral $(n=31)$. Fueron evaluados el nivel de sedación mediante la Escala de Sedación de Ramsay (RSS) y la Escala de Sedación y Agitación de Richmond (RASS); la dinámica intraoperatoria de los parámetros de los sistemas cardiovascular y respiratorio; el nivel del síndrome de dolor según la EVA. Resultados: Se determinó un alto nivel de sedación intraoperatoria en RASS $(-2,-3)$ y por Ramsay (III, IV)Al transferir un paciente a otro sector (después de 90 minutos), este parámetro fue 0 en RASS y II en Ramsay. No hubo cambios significativos en la hemodinámica central y la depresión respiratoria. El nivel mínimo de dolor se determinó después de la cirugía, 30 y 60 minutos después de la cirugía y antes del traslado al otro sector (90 minutos después): 6 (4; 9); 10 (8; 12); 12 (9; 13); 16 (13; 19), respectivamente. Se verificó que no era necesaria analgesia adicional el primer día postoperatorio. Conclusiones: El uso de D reduce significativamente el nivel de dolor al mismo tiempo que se mantiene la necesaria comunicación verbal con el paciente y brinda la protección neurovegetativa necesaria sin depresión respiratoria y parámetros hemodinámico reducidos durante el período perioperatorio. Nivel de evidencia II; Estudios de pronóstico: Investigación del efecto de la característica de un paciente sobre el desenlace de la enfermedad. Serie de casos, Estudio retrospectivo.

Descriptores: Columna Lumbar; Articulación Facetaria de Denervación con Láser; Discectomía Endoscópica Transforaminal Posterolateral; Alfa-2-adrenomiméticos; Dexmedetomidina; Cirugía de Vía Rápida; Estabilización Hemodinámica.

\section{INTRODUCTION}

Puncture methods for the surgical treatment of degenerative diseases of the lumbar spine are less traumatic and less painful methods of surgical correction when compared with traditional methods, enabling earlier return to activity and patient rehabilitation. ${ }^{1,2}$ Spine surgeons do not properly take into account the degree of anxiety and the level of pain experienced by patients when performing minimally invasive surgical interventions. ${ }^{3-5}$ The implementation of a safe perioperative period and the choice of drugs for anesthesia are aimed at the optimal combination of effective sedation with preservation of consciousness and controlled anesthesia. ${ }^{6,7}$

There is currently a search for the optimum combination of drugs capable of providing these effects when performing minimally invasive spinal procedures without respiratory depression and intubation in the forced position. Nevertheless, when adverse intraoperative consequences occur, surgical procedures should be discontinued, the patient turned over, and the safety of the respiratory system ensured. ${ }^{8,9}$ Also, when conducting surgical puncture treatment, it is important to maintain verbal contact with the patient in order to exclude iatrogenic lesions of neural structures. ${ }^{10}$ As a result, insufficient sedation and analgesia are likely to occur, increasing anxiety and pain and the risk of cardiovascular complications.

Dexmedetomidine (D), an imidazoline derivative, is a highly selective agonist of alpha2-adrenoreceptors and has sedative, analgesic, anxiolytic, and sympatholytic properties. ${ }^{11}$ The use of $D$ provides a safe depth of mental sedation with no risk of respiratory depression. ${ }^{12}$

Most of the drugs used as anesthesia in puncture techniques have several significant drawbacks: cardio- and respiratory depression, a short sedation effect, and the need for additional anesthetics and opioids. ${ }^{13,14}$ To reduce the above-mentioned risks and optimize anesthetic support for the implementation of surgical puncture techniques for intraoperative sedation, D has been used since June 2017 at the Center for Neurosurgery of the Irkutsk Railway Clinical Hospital of the Russian Railways.

The purpose of this study was to analyze the results of the use of dexmedetomidine in the treatment of patients with degenerative diseases of the lumbar spine using puncture techniques.

\section{METHODS}

A single-center study was conducted. The results were evaluated of the intraoperative and postoperative course of 77 patients operated at the Center for Neurosurgery of the Irkutsk Railway Clinical Hospital of the Russian Railways in the period January 2018 to December 2019. Patients with degenerative diseases of the lumbar spine operated by percutaneous laser denervation of the facet joints $(n=46)$ and posterior lateral transforaminal endoscopic discectomy $(n=31)$ were included in the study. The inclusion criteria were ASA classes I-III, patient's ability to understand the visual analogue scale, and tolerability of all drugs used.

In all cases, multimodal anesthesia was performed: D was administered at a dose of $1 \mu \mathrm{g} / \mathrm{kg}$ for $10-15$ minutes, followed by intravenous administration with infusomat at a dose of $0.4-0.7 \mu \mathrm{g} / \mathrm{kg} / \mathrm{h}$. Fentanyl was used as additional anesthesia, at a dose of $0.04-0.1 \mu \mathrm{g} / \mathrm{kg} / \mathrm{h}$.

The patients' sex, age, height, weight, and body mass index were determined. The efficacy of sedation using $D$ was assessed according to the RASS ${ }^{15}$ and Ramsay ${ }^{16}$ scales. Intraoperative dynamics of the cardiovascular and respiratory systems (heart rate and blood pressure) and oxygen saturation of hemoglobin $\left(\mathrm{SpO}_{2}\right)$ were evaluated, and the level of the pain was monitored, according to the visual analogue scale (VAS), before surgery, immediately after surgery, 30 and 60 minutes after surgery, and before transfer to the department (90 minutes).

Statistical processing of the results of the study was carried out using Microsoft Excel and Statistica 8.0. To assess the significance of the differences in sample populations, the criteria for nonparametric statistics were used, and the $p<0.05$ was taken as the lower confidence limit. The data are represented by the median and interquartile ranges in the form of $\mathrm{Me}(25 ; 75)$. The following criteria of nonparametric statistics were used: Mann-Whitney (M-U) for intergroup comparison, Wilcoxon (W) for dependent samples, and Pearson's chi-square test $(\chi 2)$ for binomial characteristics.

\section{RESULTS}

General information about the patients studied is presented in Table 1: the patients were mostly male, adults (35-60 years), with high nutritional status (body mass index $>25 \mathrm{~kg} / \mathrm{m} 2$ ).

All patients were operated by the same surgical team. The median duration of surgery was $56(43 ; 69) \mathrm{min}$. The use of D enabled intraoperative levels of sedation of RASS $-2,-3$ and Ramsay - III, IV to be achieved.

The intraoperative changes in the main indices of central hemodynamics are presented in Figures 1 and 2. During the dynamic assessment of the cardiovascular and respiratory parameters, there were no episodes of bradycardia (less than 10\% of the initial heart rate), arterial hypotension (less than $10 \mathrm{~mm} \mathrm{Hg}$ from the initial blood pressure) or decrease in $\mathrm{SpO}_{2}$ values (less than 98\%) registered.

In terms of pain severity, there was a significant decrease in preoperative pain levels ( $p=0.002$ ) according to the VAS. The minimum pain levels immediately after surgery, at 30 and 60 minutes, and before transfer to the department were $6(4 ; 9) ; 10(8 ; 12) ; 12$ $(9 ; 13) ; 16(13 ; 19)$, respectively (Figure 3$)$.

Studying the need for anesthesia, it was found that after the intraoperative infusion of $D$ on the first postoperative day, additional use of analgesics was not required in the vast majority of cases ( $n=64,83.1 \%$ ).

Table 1. Characteristics of the patients under study.

\begin{tabular}{c|c|c}
\hline \multicolumn{2}{c|}{ Criterion } & Study group, $\mathbf{n}=\mathbf{7 7}$ \\
\hline \multicolumn{2}{c}{ Age, yrs, Me } & $39(34 ; 53)$ \\
\hline \multirow{2}{*}{ Sex } & Male, $\mathrm{n}, \%$ & $54(70.1)$ \\
\cline { 2 - 3 } & Female, $\mathrm{n}, \%$ & $23(29.9)$ \\
\hline \multicolumn{2}{c}{ Body mass index, $\mathrm{kg} / \mathrm{m}^{2}, \mathrm{Me}$} & $26.3(23.7 ; 27.1)$ \\
\hline \multicolumn{2}{c}{ Risk of anesthesia according to ASA, Me } & $2(2.3)$ \\
\hline
\end{tabular}




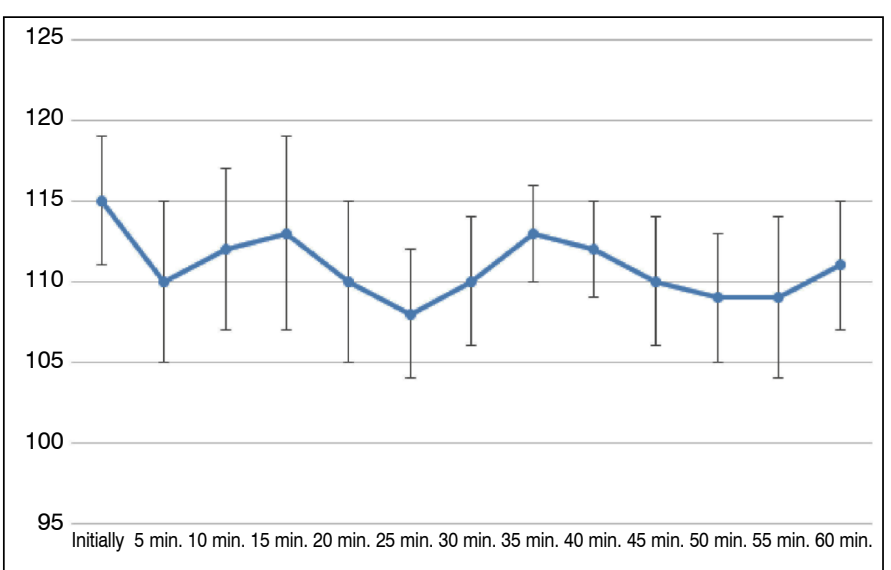

Figure 1. Intraoperative dynamics of systolic blood pressure in patients in the study group.

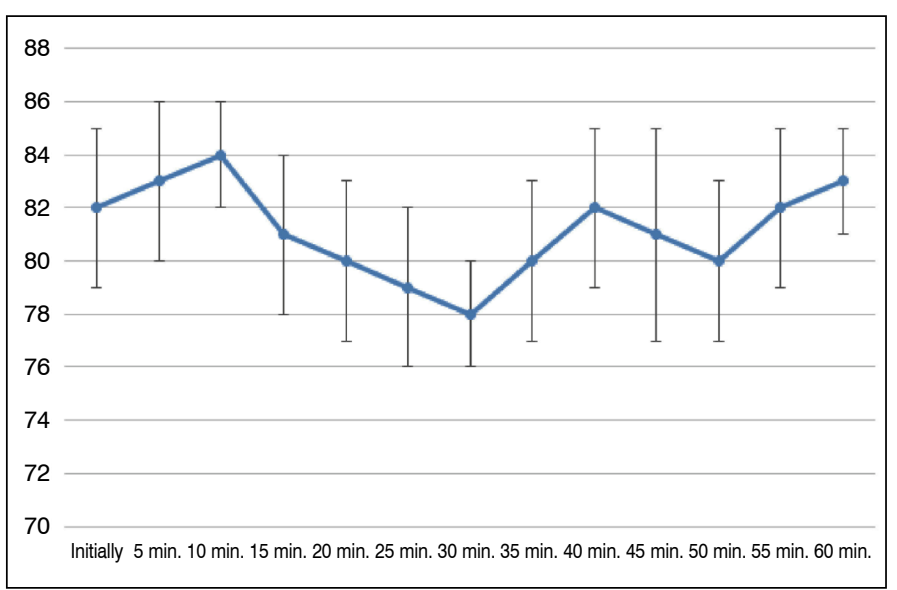

Figure 2. Intraoperative dynamics of heart rate in patients of the study group.

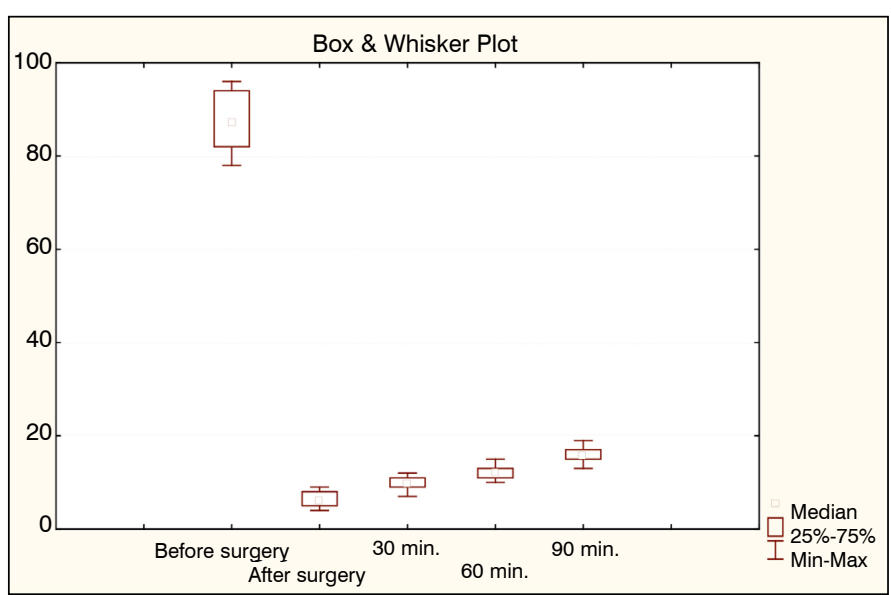

Figure 3. Postoperative dynamics of pain in patients of the study group.

The use of $D$ achieved a fairly high speed of recovery of psychomotor functions - at the moment of transfer to the department (after 90 minutes) the level of sedation corresponded to 0 on the RASS and II on the Ramsay. In such cases, the need for an extended stay in the intensive care unit is not fixed. No cases in our study required extended stays in the intensive care unit.

\section{DISCUSSION}

In the past two decades, puncture techniques such as denervation of the facet joints ${ }^{17,18}$ and posterolateral transforaminal endoscopic discectomy have been widely used to reduce painful vertebrogenic syndrome..$^{19,20}$
Many spinal surgeons indicate the possibility of using local anesthesia in minimally invasive spinal interventions. ${ }^{20,21}$ But in some cases, a low individual pain threshold and psychosomatic anxiety do not allow for adequate perioperative anesthesia, requiring use of general anesthesia. ${ }^{22}$ In these conditions, the absence of verbal contact with the patient creates a risk of iatrogenic damage to the vascular-neural formations in the presence of anomalies of the latter, as well as due to a change in the normal anatomy in degenerative diseases of the supporting elements of the spinal column.

When performing minimally invasive surgery, not only are sedation and analgesia required, but also maintenance of normal hemodynamic parameters (blood pressure and heart rate) ${ }^{23}$ Currently, propofol, benzodiazepines, and opioids are actively used as sedatives. Negative effects of their use include significant disorientation, respiratory depression and changes in hemodynamics. ${ }^{14,24}$

In general, this study confirmed the effects of $D$ that have been described by different groups of authors who have analyzed the course of anesthesia during various invasive interventions. ${ }^{25,26}$

Unlike most drugs that act through the GABAergic system and cause dose-dependent respiratory depression, D has a sedative effect by means of the adrenergic pathway, and does not change the patterns of external respiration. ${ }^{27}$

In therapeutic doses, D provides hemodynamically insignificant sympatholytic effects: it reduces the functional activity of the sinus node, has moderate vasodilation, which helps reduce the intraoperative stress reaction, and prevents the development of arterial hypertension, which is especially important in the presence of concomitant cardiovascular pathology. ${ }^{28,29}$

D favorably affects the central nervous system: sedation is achieved without changing the bioelectric activity of the brain under conditions identical to natural sleep; ${ }^{30}$ vasodilation is accompanied by an improvement in overall cerebral blood flow, without altering the intracranial pressure. ${ }^{31}$

The antinociceptive mechanism of $D$ is mainly associated with correction of the vegetative pain reaction. ${ }^{32}$ Adequate anesthesia is a necessary condition for the safety of invasive manipulations, and insufficient anesthesia during surgery can be measured by the need for postoperative analgesia. In this work, we noted a significant decrease in the severity of postoperative pain, as well as a decrease in the need for postoperative administration of analgesics.

The study confirms the properties of $D$ aimed at stabilizing intraoperative hemodynamics, while minimizing cardio- and respiratory depression.

In spinal surgery, experience in use of D is minimal, and is based on studies that emphasize the importance of early awakening of patients for assessment of neurological status. ${ }^{33,34}$ In addition, after multilevel fusion, faster functional recovery and decreased blood cytokines and cortisol levels were observed in the group of patients using $D$, compared with the control group. ${ }^{35}$ Thus, taking into account the insufficient amount of information on the use of $D$ for vertebrogenic surgical interventions in the specialized literature, this work is considered relevant.

\section{CONCLUSION}

The study showed high efficiency and safety of intraoperative sedation with dexmedetomidine, enabling a significant reduction in pain while maintaining the necessary verbal contact with the patient.

The use of dexmedetomidine provides sufficient analgesia and neurovegetative protection without lowered respiratory or hemodynamic levels during the perioperative period.

Further research is required for comparative analysis of various multimodal anesthesia regimens for the provision of anesthesia in patients with vertebrogenic profile.

All authors declare no potential conflict of interest related to this article. 
CONTRIBUTIONS OF THE AUTHORS: Each author made significant individual contributions to this manuscript. VAB and VYG were the main contributors to the drafting of the manuscript. VAB, VYG, AAK, performed the surgery and anesthesia, collected patient follow-up data and gathered clinical data. AAK and MYB evaluated the data from the statistical analysis. VAB, VYG, AAK and MYB performed the literature search and review of the manuscript, and contributed to the intellectual concept of the study.

\section{REFERENCES}

1. Belykh E, Carotenuto A, Kalinin AA, Akshulakov SK, Kerimbayev T, Borisov VE, et al. Surgical Protocol for Infections, Nonhealing Wound Prophylaxis, and Analgesia: Development and Implementation for Posterior Spinal Fusions. World Neurosurg. 2019;123:390-401. doi: 10.1016/j. wneu.2018.11.135.

2. Byvaltsev VA, Kalinin AA, Konovalov NA. Minimal'no invazivnaia khirurgiia pozvonochnika: étapy razvitiia [Minimally invasive spinal surgery: stages of development]. Zh Vopr Neirokhir Im N N Burdenko. 2019;83(5):92-100. [Article in Russian]. doi: 10.17116/neiro20198305192.

3. Belykh E, Kalinin AA, Martirosyan NL, Kerimbayev T, Theodore N, Preul MC, et al. Facet Joint Fixation and Anterior, Direct Lateral, and Transforaminal Lumbar Interbody Fusions for Treatment of Degenerative Lumbar Disc Diseases: Retrospective Cohort Study of a New Minimally Invasive Technique. World Neurosurg. 2018;114:e959-68. doi: 10.1016/j.wneu.2018.03.121.

4. Glaess SS, Attridge RL, Christina Gutierrez G. Clonidine as a strategy for discontinuing dexmedetomidine sedation in critically ill patients: A narrative review. Am J Health Syst Pharm. 2020;77(7):515-22. doi: 10.1093/ajhp/zxaa013.

5. Carrasco G, Baeza N, Cabré L, Portillo E, Gimeno G, Manzanedo D, et al. Dexmedetomidine for the Treatment of Hyperactive Delirium Refractory to Haloperidol in Nonintubated ICU Patients: A Nonrandomized Controlled Trial. Crit Care Med. 2016;44(7):1295-306. doi: 10.1097/CCM.0000000000001622.

6. Coeckelenbergh S, Doria S, Patricio D, Perrin L, Engelman E, Rodriguez A, et al. Effect of dexmedetomidine on Nociception Level Index-guided remifentanil antinociception: A randomised controlled trial. Eur J Anaesthesiol. 2021;38(5):524-33. doi: 10.1097/EJA.0000000000001402.

7. Grape S, Kirkham KR, Frauenknecht J, Albrecht E. Intra-operative analgesia with remifentanil vs. dexmedetomidine: a systematic review and meta-analysis with trial sequential analysis. Anaesthesia. 2019;74(6):793-800. doi: 10.1111/anae.14657

8. Janssen TL, Alberts AR, Hooft L, Mattace-Raso F, Mosk CA, van der Laan L. Prevention of postoperative delirium in elderly patients planned for elective surgery: systematic review and meta-analysis. Clin Interv Aging. 2019;14:1095-117. doi: 10.2147/CIA.S201323.

9. Di Cesare Mannelli L, Micheli L, Crocetti L, Giovannoni MP, Vergelli C, Ghelardini C. $\alpha 2$ Adrenoceptor: a Target for Neuropathic Pain Treatment. Mini Rev Med Chem. 2017;17(2):95-107. doi: 10.2174/1389557516666160609065535.

10. Mao S, Zhu C, Chang Y. Effects of different anesthesia methods on postoperative transient neurological syndrome in patients with lumbar disc herniation. Exp Ther Med. 2017;14(4):3112-6. doi: 10.3892/etm.2017.4900.

11. Romagnoli S, Amigoni A, Blangetti I, Casella G, Chelazzi C, Forfori F, et al. Light sedation with dexmedetomidine: a practical approach for the intensivist in different ICU patients. Minerva Anestesiol. 2018;84(6):731-46. doi: 10.23736/S03759393.18.12350-9.

12. Kaye AD, Chernobylsky DJ, Thakur P, Siddaiah H, Kaye RJ, Eng LK, et al. Dexmedetomidine in Enhanced Recovery After Surgery (ERAS) Protocols for Postoperative Pain. Curr Pain Headache Rep. 2020;24(5):21. doi: 10.1007/s11916-020-00853-z.

13. Bajwa SJ, Haldar R. Pain management following spinal surgeries: an appraisal of the available options. J Craniovertebr Junction Spine. 2015;6(3):105-10. doi: 10.4103/09748237.161589.

14. Li WX, Luo RY, Chen C, Li X, Ao JS, Liu Y, et al. Effects of propofol, dexmedetomidine, and midazolam on postoperative cognitive dysfunction in elderly patients: a randomized controlled preliminary trial. Chin Med J (Engl). 2019;132(4):437-45. doi: 10.1097/CM9.0000000000000098.

15. Sessler CN, Gosnell MS, Grap MJ, Brophy GM, O'Neal PV, Keane KA, et al. The Richmond Agitation-Sedation Scale: validity and reliability in adult intensive care unit patients. Am J Respir Crit Care Med. 2002;166(10):1338-44. doi: 10.1164/rccm.2107138.

16. Olson D, Lynn M, Thoyre SM, Graffagnino C. The limited reliability of the Ramsay scale. Neurocrit Care. 2007:7(3):227-31. doi: 10.1007/s12028-007-0069-X.

17. Eldabe S, Tariq A, Nath S, Gulve A, Antrobus $H$, Baloch $M$, et al. Best practice in radiofrequency denervation of the lumbar facet joints: a consensus technique. $\mathrm{Br} J$ Pain. 2020;14(1):47-56. doi: 10.1177/2049463719840053.

18. Balázsfi $M$, Kis $D$, Tóth $T$, Zsoldos $T$, Barzó $P$. Radiofrequency facet joint denervation efficiency based on the severity of spondylarthrosis and in osteoporotic vertebral compression fractures. A retrospective study. Clin Neurol Neurosurg. 2019:186:105497. doi: 10.1016/j.clineuro.2019.105497.

19. Ceylan A, Așık I. Percutaneous navigable intradiscal decompression in treatment of lumbar disc herniation: a single-center experience. Turk J Med Sci. 2019;49(2):51924. doi: $10.3906 / \mathrm{sag}-1805-187$

20. Clark R, Weber RP, Kahwati L. Surgical Management of Lumbar Radiculopathy: a Systematic Review. J Gen Intern Med. 2020;35(3):855-64. doi: 10.1007/s11606-019-05476-8.

21. Woiciechowsky C, Richter LM. Endoscopic 4-MHz Radiofrequency Treatment of Face Joint Syndrome Is More Than Just Denervation: One Incision for Three Facets. J Neurol Surg A Cent Eur Neurosurg. 2020;81(3):238-42. doi: 10.1055/s-0039-1698397.

22. Fang G, Ding Z, Song Z. Comparison of the Effects of Epidural Anesthesia and Local Anesthesia in Lumbar Transforaminal Endoscopic Surgery. Pain Physician. 2016;19(7):E1001-4

23. Bavullu EN, Aksoy E, Abdullayev R, Göğüş N, Dede D. Comparison of dexmedetomidine and Midazolam in Sedation for Percutaneous Drainage of Hepatic Hydatid Cysts. Turk J Anaesthesiol Reanim. 2013:41(6):195-9. doi: 10.5152/TJAR.2013.40.

24. Eren G, Cukurova Z, Demir G, Hergunsel O, Kozanhan B, Emir NS. Comparison of dexmedetomidine and three different doses of midazolam in preoperative sedation. J Anaesthesio Clin Pharmacol. 2011;27(3):367-72. doi: 10.4103/0970-9185.83684

25. Blaudszun G, Lysakowski C, Elia N, Tramèr MR. Effect of perioperative systemic $\alpha 2$ agonists on postoperative morphine consumption and pain intensity: systematic review and meta-analysis of randomized controlled trials. Anesthesiology. 2012;116(6):1312-22. doi 10.1097/ALN.0b013e31825681cb

26. Subramaniam B, Shankar P, Shaefi S, Mueller A, O'Gara B, Banner-Goodspeed V, et al. Effect of Intravenous Acetaminophen vs Placebo Combined With Propofol or Dexmedetomidine on Postoperative Delirium Among Older Patients Following Cardiac Surgery: The DEXACET Randomized Clinical Trial. JAMA. 2019;321(7):686-96. doi: 10.1001/jama.2019.0234.

27. Brown EN Pavone KJ Naranjo M. Multimodal General Anesthesia: Theory and Practice. Anesth Analg. 2018;127(5):1246-58. doi: 10.1213/ANE.0000000000003668.

28. Frölich MA, Arabshahi A, Katholi C, Prasain J, Barnes S. Hemodynamic characteristics of midazolam, propofol, and dexmedetomidine in healthy volunteers. J Clin Anesth. 2011;23(3):218-23. doi: 10.1016/j.jclinane.2010.09.006

29. Rao SH, Sudhakar B, Subramanyam PK. Haemodynamic and anaesthetic advantages of dexmedetomidine. South Afr J Anaesth Analg. 2012:18(6):326-31. doi: 10.1620/tjem. 210.153

30. Wahood W, Yolcu Y, Alvi MA, Goyal A, Long TR, Bydon M. Assessing the differences in outcomes between general and non-general anesthesia in spine surgery: Results from a national registry. Clin Neurol Neurosurg. 2019;180:79-86. doi: 10.1016/j. clineuro.2019.03.021

31. Peng K, Wu S, Liu H, Ji F. Dexmedetomidine as an anesthetic adjuvant for intracranial procedures: meta-analysis of randomized controlled trials. J Clin Neurosci. 2014:21(11):1951-8. doi: 10.1016/j.jocn.2014.02.023.

32. Moshiri E, Modir H, Bagheri N, Mohammadbeigi A, Jamilian H, Eshrati B. Premedication effect of dexmedetomidine and alfentanil on seizure time, recovery duration, and hemodynamic responses in electroconvulsive therapy. Ann Card Anaesth. 2016:19(2):263-8. doi: 10.4103/0971-9784.179618

33. Barends CR, Absalom A, van Minnen B, Vissink A, Visser A. Dexmedetomidine versus Midazolam in Procedural Sedation. A Systematic Review of Efficacy and Safety. PLoS One. 2017;12(1):e0169525. doi: 10.1371/journal.pone.0169525.

34. Lee S. Dexmedetomidine: present and future directions. Korean J Anesthesiol. 2019;72(4):323-30. doi: 10.4097/kja.19259.

35. Bekker A, Haile M, Kline R, Didehvar S, Babu R, Martiniuk F, et al. The effect of intraoperative infusion of dexmedetomidine on the quality of recovery after major spinal surgery. J Neurosurg Anesthesiol. 2013;25(1):16-24. doi: 10.1097/ANA.0b013e31826318af. 